\title{
DEVELOPMENT OF A GREENHOUSE BY USING SOLAR ENERGY FOR PRODUCING PEPPER CROP
}

\author{
A. M. Elsbaay*
}

\section{ABSTRACT}

This study aimed to utilization of solar energy as a renewable energy source to enhance the environment of greenhouse for pepper crop production through comparing between two greenhouses. Two semicircle greenhouses $(30 \mathrm{~m} \times 6 \mathrm{~m} \times 3 \mathrm{~m})$ were used to achieve the objective of this study. The solar collector with vacuum tubes was used for heating greenhouse (developed greenhouse). The second, greenhouse without any heating sources (traditional greenhouse). This study indicated that the heating system for greenhouse has a big effect of temperature distribution uniformity inside the greenhouse. The soil temperatures for developed greenhouse were 17.2, 16.49, 16.68 and $17.11{ }^{\circ} \mathrm{C}$ at soil depth $5,10,15$ and $20 \mathrm{~cm}$ respectively. The highest values of ultra violet (UV) dose were 13 and $10.2 \mathrm{~mJ} . \mathrm{cm}^{-2}$ for developed greenhouse and traditional greenhouse respectively. The highest values of heating degree day (HDD) were $0.3{ }^{\circ} \mathrm{C}$ and $0.1{ }^{\circ} \mathrm{C}$ for traditional greenhouse and developed greenhouse respectively. Generally, the developed greenhouse was lower needy to cooling degree day (CDD) and HDD than traditional greenhouse. The heating system for developed greenhouse has a significant agronomic effect especially on the precocity of the production. Developed greenhouse was better than traditional greenhouse for all vegetative growth of pepper plant parameters. Pepper crop specification of developed greenhouse yield was better than traditional greenhouse especially second packing for all early yield and yield components of pepper plant parameters.

Key words: solar energy, heating, greenhouse, pepper production

\section{INTRODUCTION}

7 he climatic conditions of the region are the prime factor, which effect the development of the plant and the economics of the

greenhouse production. It becomes necessary to take measures to

* Lecturer Agricultural Engineering Department, Faculty of Agriculture, Kafrelsheikh University, EGYPT. E-mail: atef.ahmed@agr.kfs.edu.eg 
heat the greenhouses when the temperature goes below $12{ }^{\circ} \mathrm{C}$ in order to obtain high quality and high yield crop, that is especially important for export purpose (Zabeltitz 1992 and Mezrhab et al. 2010).

The use of greenhouses for crops has increased manifold over recent decades in the world. To maintain a suitable environment for the production of various crops, enormous fossil fuel has been used for heating the greenhouse in winter. A novel solar heating system with thermal energy collected by solar system has been proposed to reduce the fossil fuel consumption. The use of solar energy is considerable interest for two reasons. First, it leads to diminution of fossil fuels consumption. Second, solar energy is a non-polluting source of energy (Badescu, 2002).

Heating greenhouses during nights and cold days has a significant effect on the quality and the cultivation time of products. In a greenhouse, maintaining ideal ambient temperature requires large amounts of thermal energy and this is generally supplied by fossil fuels (Chinese et al. 2005; Bargach et al. 1999 and Bargach et al. 2004).

In addition to solar energy gain, greenhouses should be heated during nights and cold days. In order to establish optimum growth conditions in greenhouses, renewable energy sources should be utilized as much as possible (Ozgener and Kocer 2004). Heating applications in the greenhouses have an important effect on yield as well as on quality and the cultivation time of products (Ozgener et al. 2011, Teitel et al. 2009 and Ghosal et al. 2004). This study aimed to utilization of solar energy as a renewable energy source for enhancing the environment of greenhouse for pepper crop production and comparing developed greenhouse with traditional greenhouse.

\section{MATERIALS AND METHODS}

The experiments were carried out during the winter season 2012/2013 and installed in Faculty of Agriculture farm, Kafrelsheikh University, Kafr El-Sheikh Governorate, Egypt ( $\left.31^{\circ} 06^{\prime} \mathrm{N}-30^{\circ} 56^{\prime} \mathrm{E}\right)$. Two semicircle greenhouses $(30 \mathrm{~m} \times 6 \mathrm{~m} \times 3 \mathrm{~m})$ were used to achieve the objective of this study (developed greenhouse and traditional greenhouse). The 
greenhouses were covered with a single polyethylene sheet of $0.2 \mathrm{~mm}$ thickness. The two greenhouses were prepared and planted with pepper (Capsicum annuum) seedlings. Longitudinal axis of the greenhouse was oriented to North-South to talk the maximum benefit from the sun during winter. The total area under the greenhouse is $180 \mathrm{~m}^{2}$ with the dimensions as $30 \times 6 \mathrm{~m}$. The experimental greenhouse has 3 lines with 1 $\mathrm{m}$ width. On the other hand, every line was coated with black plastic sheet. The greenhouses were planted with pepper and irrigated with drip irrigation system.

The greenhouse was prepared with heat exchanger. The heat exchanger consists of iron pipes and polyvinyl chloride pipes (PVC). The pipes have diameter $5 \mathrm{~cm}$ and extends along the length of the greenhouse (30 $\mathrm{m})$. Pipes were insulated with glass wool thickness of $3 \mathrm{~cm}$ from the outlet of the heater until the beginning of the entrance to the greenhouse and soil-buried and then continue into the greenhouse without insulation and extends between plants and lines at a height of $10 \mathrm{~cm}$ from the surface of the soil. This heat exchanger works on the heating greenhouse, especially beside to the plants as well as heating the soil around the roots of the plant, through the push hot water in the pipes. The water comeback to outside the greenhouse in isolated and buried pipes to pour into in the tank heater for cold water to be withdrawn and heated and pumped back to the heater - hot water tank - and so are the heating cycle. As illustrated in the (Fig. 1). The water pump was used in the heating system have 0.75 $\mathrm{kW}$ power and $0.85 \mathrm{~m}^{3}$ mint $^{-1}$ water discharge Greenhouse heating system depends on heating water using solar water heater. Evacuated tube Collector (ETC) was used in this study which is characterized by high efficiency, especially during non-sunny and cool weather in the presence of strong winds. This is in addition to the decrease in affected basic parts with weather factors such as moisture condensation, therefore its parts as not to damage quickly and then increase the efficiency of performance throughout the shelf life. 


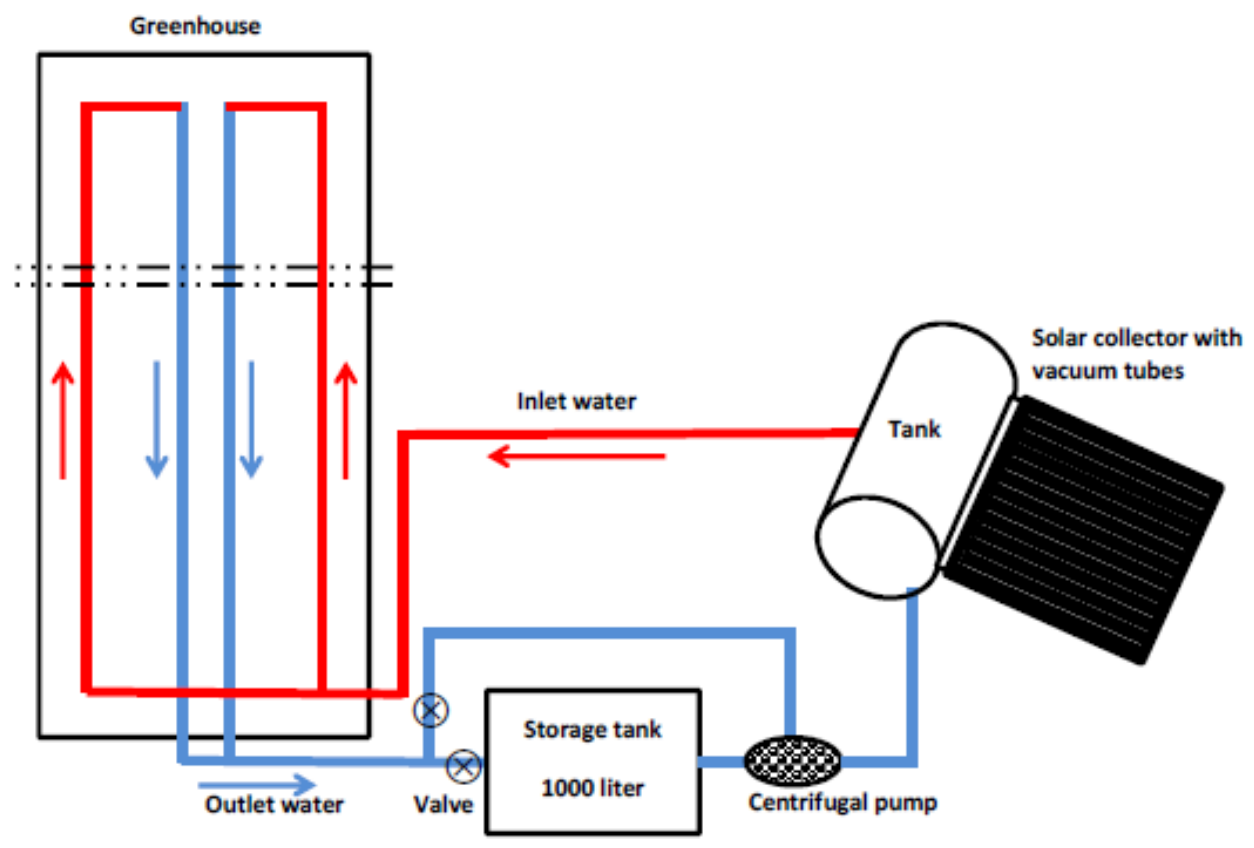

Fig.1: Schematic diagram show the experimental system of solar collector with heat exchanger and greenhouse (developed greenhouse).

It also works more efficiently at low angle of incidence, giving it higher performance efficiency for the length of the day. The heater consists of a reservoir and a set of heat pipes (Fig. 2).

The greenhouse was divided into three zones longitudinally right, middle and lift as well as accidental front, middle and end to identify areas of measurement (Fig. 3).

The temperatures inside the greenhouses were recorded, as well as the temperature of the soil around the plant on four different depths were 5, 10,15 and $20 \mathrm{~cm}$ and in various areas inside the greenhouse according Fig. 3. Davis vantage pro2 weather station was used for recording weathering data. By Davis weather station we will get all current weather conditions including; wind speed, wind direction, outside and inside temperature and humidity, barometric pressure, rainfall, solar radiation, UV, a weather forecast. The agronomic performance of pepper crop was calculated as average of twenty plants. 
The Heat Index (also called apparent temperature) is a measure of the stress placed on plants by elevated levels of surrounding temperature and moisture. As the surrounding moisture content increases,

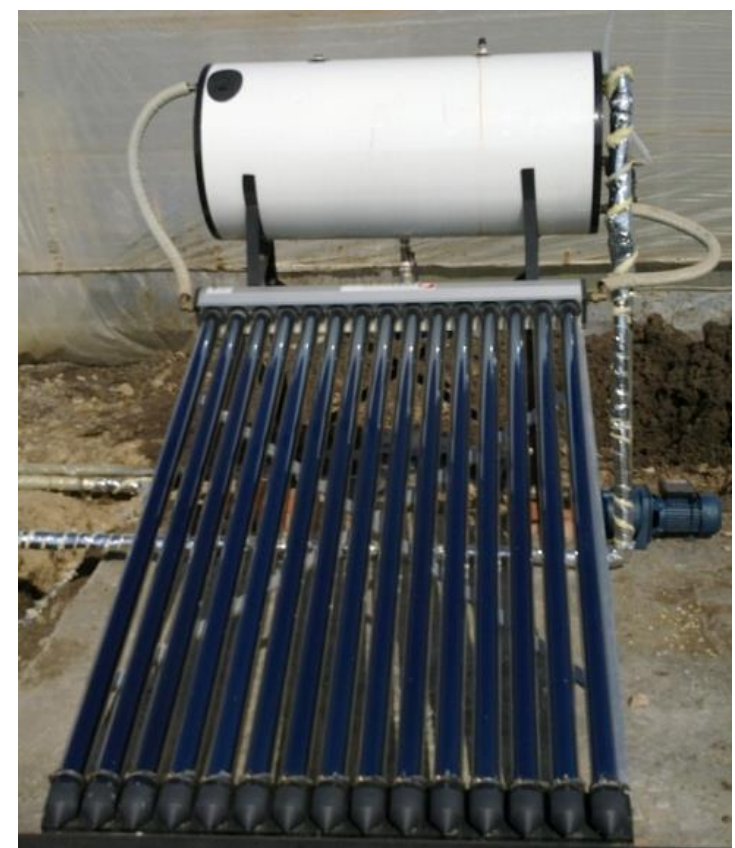

Fig. 2: Actual evacuated tube collector installation

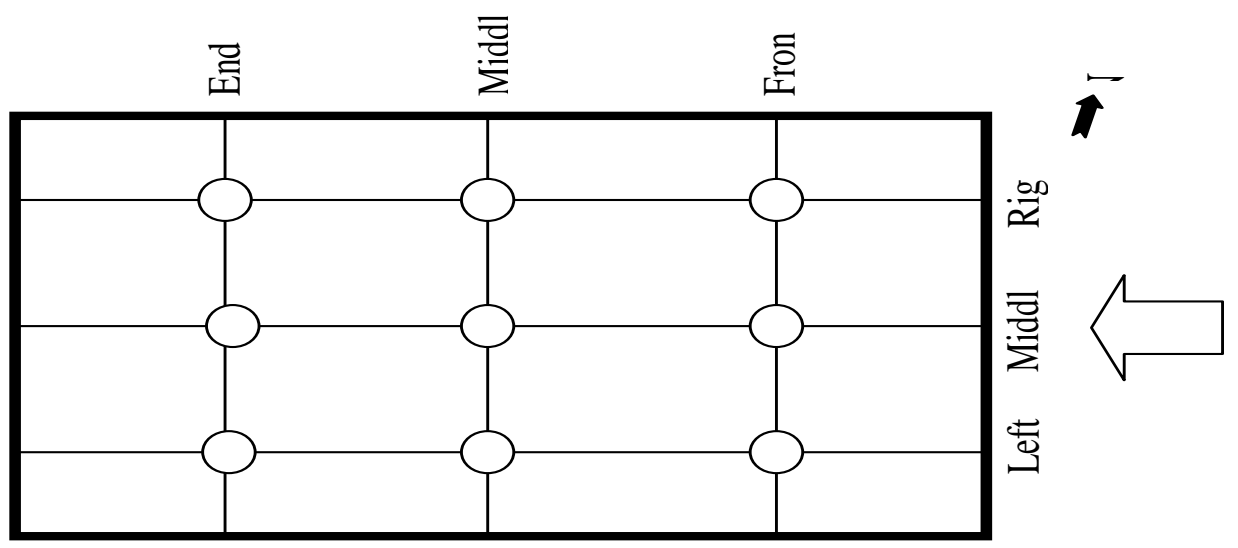

Fig.3: Shows a sketch of the greenhouse plan showing the areas of measurement 
the ability of the plant to release heat through evaporation is inhibited, thereby causing discomfort and stress. (Wikimedia Foundation 2010) calculated the heat index as follows:

Heat Index $=\mathrm{C}_{1}+\mathrm{C}_{2} \mathrm{~T}+\mathrm{C}_{3} \mathrm{R}+\mathrm{C}_{4} \mathrm{TR}+\mathrm{C}_{5} \mathrm{~T}^{2}+\mathrm{C}_{6} \mathrm{R}^{2}+\mathrm{C}_{7} \mathrm{~T}^{2} \mathrm{R}+\mathrm{C}_{8} \mathrm{TR}^{2}$ $+\mathrm{C}_{9} \mathrm{~T}^{2} \mathrm{R}^{2}$

Where:

$c_{1}=-42.379$ $c_{2}=-2.04901523$

$c_{3}=-10.14333127$

$\mathrm{c}_{4}=-0.22475541$ $c_{5}=-6.83783 \times 10^{-3}$

$\mathrm{c}_{6}=-5.481717 \times 10^{-2}$

$\mathrm{c}_{7}=-1.22874 \times 10^{-3}$ $\mathrm{c}_{8}=8.5282 \times 10^{-4}$

$c_{9}=-1.99 \times 10^{-6}$

$\mathrm{T}=$ air temperature, $\mathrm{F}^{\circ}$

$\mathrm{R}=$ relative humidity

Calculating heat loss is the first step in determining the heating system capacity of greenhouse before selecting the system and its components. Therefore, the heating system should be properly sized to meet the needs of the greenhouse under extreme weather conditions. Greenhouse heat loss is calculated by the following equation (Esen and Yuksel 2013):

$Q_{G H L}=\left(\frac{A_{1}}{R_{1}}+\frac{A_{2}}{R_{2}}+\cdots\right)\left(T_{i}-T_{o}\right)\left(f_{w}\right)\left(f_{c}\right)\left(f_{s}\right)$

$\mathrm{Q}_{\mathrm{GHL}} \quad$ rate of greenhouse heat losses $(\mathrm{kW})$.

$A_{1}, A_{2}$ surface area of various components in greenhouse $\left(\mathrm{m}^{2}\right)$

$R_{1}, R_{2}$ thermal resistance of each component in greenhouse $\left(0.3 \mathrm{~m}^{2}\right.$ 。

$\mathrm{CW}^{-1}$ )

$\mathrm{T}_{\mathrm{i}} \quad$ inside design temperature of greenhouse $\left(\mathrm{K},{ }^{\circ} \mathrm{C}\right)$

$\mathrm{T}_{\mathrm{o}} \quad$ outside design temperature of greenhouse $\left(\mathrm{K},{ }^{\circ} \mathrm{C}\right)$

$\mathrm{f}_{\mathrm{w}} \quad$ wind or exposure factor for greenhouse

$f_{c} \quad$ construction type or quality factor for greenhouse

$\mathrm{f}_{\mathrm{S}} \quad$ system factor for greenhouse

$$
\begin{aligned}
& \mathrm{A}_{1}=(3.14)(3)(30)=282.6 \mathrm{~m}^{2} \\
& \mathrm{~A}_{2}=\left(3.14 \times 3^{2}\right)=28.26 \mathrm{~m}^{2}
\end{aligned}
$$


For greenhouse energy balance, the solar energy system is composed in our case of these elements, the cover of greenhouse, the inside air, the vegetation and the soil surface. Energy equilibrium equations are therefore necessary to describe the system (Fig. 4).

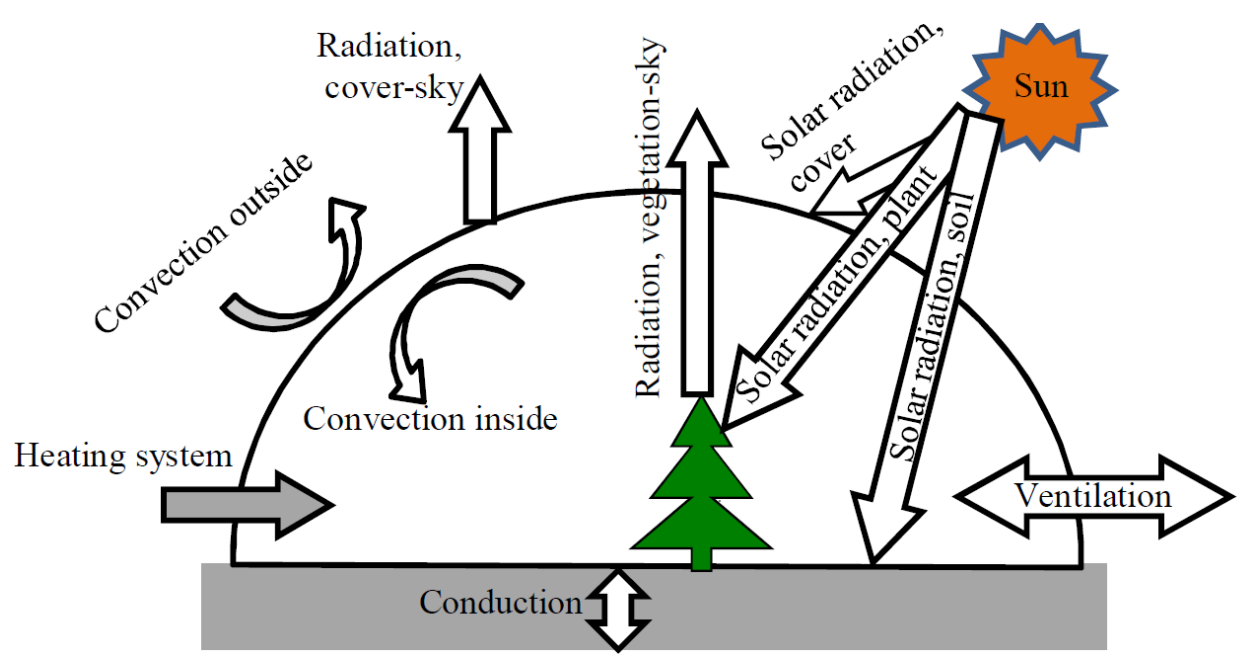

Fig. 4: Energy balance and fluxes of the components of the greenhouse.

For the different components of the greenhouse, the energy balance equations can be written as according to (De Halleux, 1989; Wang et al., 1990; Zhang et al. 1993; De Halleux et al., 1991; Bargach et al., 1999 and Gamea et al., 2011)

Energy equilibrium equation for the cover:

$\mathrm{Q}_{\mathrm{rd}(\mathrm{so}-\mathrm{co})}+{ }_{\mathrm{Qrd}(\mathrm{pl}-\mathrm{co})}+\mathrm{Q}_{\mathrm{rd}(\mathrm{co-sky})}+\mathrm{Q}_{\mathrm{cv}(\text { air)ins }}+\mathrm{Q}_{\mathrm{cv}(\text { air)out }}+\mathrm{Q}_{\text {conden }}=0$

where $\mathrm{Q}_{\mathrm{rd}(\mathrm{so}-\mathrm{co})}$, $\operatorname{Qrd}(\mathrm{pl}-\mathrm{co})$ and $\mathrm{Q}_{\mathrm{rd}(\mathrm{co}-\mathrm{sky})}$ are the radiative flux densities $\left(\mathrm{W} . \mathrm{m}^{-2}\right)$, respectively from the greenhouse soil surface to the cover, from the vegetation to the cover and from the cover to the sky, $Q_{\mathrm{cv}(\mathrm{air}) i n s}$, $\mathrm{Q}_{\mathrm{cv}(\mathrm{air}) \mathrm{out}}$ is the convective exchange $\left(\mathrm{W} \cdot \mathrm{m}^{-2}\right)$, respectively occurring between the air interior and exterior, $\mathrm{Q}_{\text {conden }}$ is the latent heat of condensation (W. $\mathrm{m}^{-2}$ ).

Energy equilibrium equation for the interior air shown in the following equation:

$\mathrm{Q}_{\mathrm{cv}(\mathrm{pl})}+\mathrm{Q}_{\mathrm{cv}(\mathrm{so})}+\mathrm{Q}_{\mathrm{cv}(\mathrm{co})}+\mathrm{Q}_{\mathrm{h}}+\mathrm{Q}_{\mathrm{vent}}=0$ 
where $\mathrm{Q}_{\mathrm{cv}(\mathrm{pl})}, \mathrm{Q}_{\mathrm{Cv}(\mathrm{so})}$ and $\mathrm{Q}_{\mathrm{cv}(\mathrm{co})}$ are the convective flux densities (W.m ${ }^{-2}$ ), respectively occurring between the soil surface and the interior air, between the vegetation and the interior air and between the cover and interior air, $\mathrm{Q}_{\mathrm{h}}$ is the total heat flux due to the heating system $\left(\mathrm{W} . \mathrm{m}^{-2}\right)$, $\mathrm{Q}_{\text {vent }}$ is the thermic flux due to ventilation $\left(\mathrm{W} . \mathrm{m}^{-2}\right.$ ).

The soil surface gains heat from thermal radiations emitted through greenhouse cover and absorbed by the soil surface and the thermal radiation from the heating system. The soil in the greenhouse is considered a large heat storage element (Tantau, 1998). It lose heat through the thermal radiations emitted by the soil surface, conduction through the soil and convective heat transfer from the soil surface to the inside air.

$\mathrm{Q}_{\mathrm{G}(\mathrm{SO})}+\mathrm{Q}_{\mathrm{rd}(\mathrm{pl}-\mathrm{so})}+\mathrm{Q}_{\mathrm{rd}(\mathrm{co}-\mathrm{so})}+\mathrm{Q}_{\mathrm{cv}(\mathrm{so})}+\mathrm{Q}_{\mathrm{cd}}+\mathrm{Q}_{\text {evap }}+\mathrm{Q}_{\text {heat }}=0$

Where:

$\mathrm{Q}_{\mathrm{G}(\mathrm{SO})}$ is the solar energy absorbed by the soil, $\left(\mathrm{W} \cdot \mathrm{m}^{-2}\right)$

$\mathrm{Q}_{\mathrm{rd}(\mathrm{pl}-\mathrm{so})}$ is the radiation exchange between plant and the soil, $\left(\mathrm{W} . \mathrm{m}^{-2}\right)$

$\mathrm{Q}_{\mathrm{rd}(\mathrm{co-so})}$ is the radiation exchange between cover and the soil, (W. $\left.\mathrm{m}^{-2}\right)$

$\mathrm{Q}_{\mathrm{cv}(\mathrm{so})}$ is the heat flux due to convection from soil to air, (W. $\mathrm{m}^{-2}$ )

$\mathrm{Q}_{\mathrm{cd}}$ is the rate of energy loss from the soil to the ground depth, (W. $\left.\mathrm{m}^{-2}\right)$

$\mathrm{Q}_{\text {evap }}$ is the thermal heat loss from greenhouse soil due to evaporation, (W. $\mathrm{m}^{-2}$ )

$\mathrm{Q}_{\text {heat }}$ is the thermal radiation from the heating system, $\left(\mathrm{W} . \mathrm{m}^{-2}\right)$

Energy equilibrium for the other soil layers:

For the first soil layer: $\frac{d T_{s 1}}{d t}=\frac{Q_{c d s 1}}{\rho_{s 1} C_{s 1} l_{s 1}}-\frac{Q_{c d s 2}}{\rho_{s 2} C_{s 2} l_{s 2}}$

For the second soil layer: $\frac{d T_{s 2}}{d t}=\frac{Q_{c d s 2}}{\rho_{s 2} C_{s 2} l_{s 2}}-\frac{Q_{c d s 3}}{\rho_{s 3} C_{s 3} l_{s 3}}$

For the third soil layer: $\frac{d T_{s 3}}{d t}=\frac{Q_{c d s 3}}{\rho_{s 3} C_{s 3} l_{s 3}}-\frac{Q_{c d s 4}}{\rho_{s 4} C_{s 4} l_{s 4}}$

For the fourth soil layer: $\frac{d T_{s 4}}{d t}=\frac{1}{\rho_{s 4} C_{s 4} l_{s 4}}\left(Q_{c d s 4}-Q_{c d s s}\right)$

Where $\mathrm{Q}_{\mathrm{cds} 1}, \mathrm{Q}_{\mathrm{dcs} 2}, \mathrm{Q}_{\mathrm{dcs} 3}$ and $\mathrm{Q}_{\mathrm{dcs} 4}$ are the conductive flux densities respectively through the first soil layer, second soil layer, the third soil layer and the fourth soil layer, $\mathrm{Q}_{\mathrm{cdss}}$ is the conductive flux density through the underground layer, $\rho_{\mathrm{s} 1}, \rho_{\mathrm{s} 2}, \rho_{\mathrm{s} 3}$ and $\rho_{\mathrm{s} 4}$ are the respective 
densities, $\mathrm{C}_{\mathrm{s} 1}, \mathrm{C}_{\mathrm{s} 2}, \mathrm{C}_{\mathrm{s} 3}$ and $\mathrm{C}_{\mathrm{s} 4}$ are the respective thermic capacities, $l_{\mathrm{s} 1}, l_{\mathrm{s} 2}$, $l_{\mathrm{s} 3}$ and $l_{\mathrm{s} 4}$ are the respective thickness of the four soil layers.

The greenhouse crop system can be cosidered as a solar collector involving both sensible and latent heat exchanges and its thermal performances can be discribed in a similar way by using energy balance equation (Seginer and Alberight 1980). Part of the energy absorbed by the plants is transferred to latent heat due to transpiration was mentioned in the following equation (Boulard et al. 1990).

$\mathrm{Q}_{\mathrm{G}(\mathrm{pl})}+\mathrm{Q}_{\mathrm{rd}(\mathrm{pl}-\mathrm{co})}+\mathrm{Q}_{\mathrm{rd}(\mathrm{pl}-\mathrm{so})}+\mathrm{Q}_{\mathrm{cv}(\mathrm{pl})}+\mathrm{Q}_{\text {trans }}=0$

Where:

$\mathrm{Q}_{\mathrm{G}(\mathrm{pl})}$ is the solar energy absorbed by plant surface, $\left(\mathrm{W} \cdot \mathrm{m}^{-2}\right)$

$\mathrm{Q}_{\mathrm{rd}(\mathrm{pl}-\mathrm{co})}$ is the radiation exchange between plant and cover, $\left(\mathrm{W} \cdot \mathrm{m}^{-2}\right)$

$\mathrm{Q}_{\mathrm{rd}(\mathrm{pl}-\mathrm{so})}$ is the radiation exchange between plant and the soil, $\left(\mathrm{W} \cdot \mathrm{m}^{-2}\right)$

$\mathrm{Q}_{\mathrm{cv}(\mathrm{pl})}$ is the heat flux due to convection from plant to air, $\left(\mathrm{W} \cdot \mathrm{m}^{-2}\right)$

$\mathrm{Q}_{\text {trans }}$ is the heat flux due to transpiration, $\left(\mathrm{W} . \mathrm{m}^{-2}\right)$

Among the flux densities defined in equations (3) - (10), some will be counterbalanced by the others, in such a way that the thermal global balance can be described by only one equation that takes into account the difference between the total supplies and the total losses:

$\sum$ Supplies $-\sum$ Losses $=$ Instantaneous variation of the greenhouse internal energy

\section{RESULTS AND DISCUSSION}

(Fig. 5) shows the hourly solar radiation and hourly temperature on $26^{\text {th }}$ November. The average length of the day was about 10 hours. The highest value of the solar radiation during the period of the experiment was about $800 \mathrm{~W} . \mathrm{m}^{-2}$ were often occur in the middle of the daylight and was followed by a rise in solar radiation at high temperature also. The average temperature through the daylight and day night were $18.5^{\circ} \mathrm{C}$ and $11.8^{\circ} \mathrm{C}$ respectively.

\subsection{Greenhouse temperature:}

\subsubsection{Soil temperature inside greenhouse:}

The temperature inside the greenhouse has a big effect at pepper crop growth especially soil temperature surrounding the plant root. 


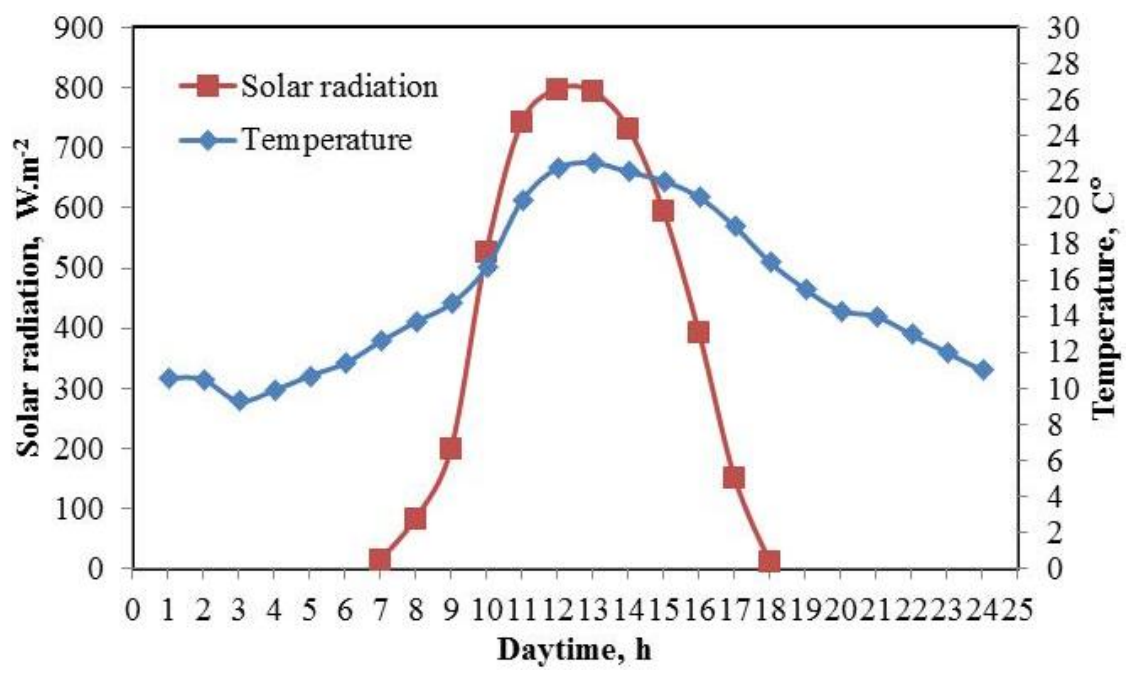

Fig. 5: Presents average measured hourly temperature and total solar radiation on horizontal surface on $26^{\text {th }}$ November 2012

This study investigated that, generally the soil temperature for developed greenhouse was higher than traditional greenhouse at all studied soil depths (Fig. 6). The soil temperature for developed greenhouse were 17.2, 16.49, 16.68 and $17.11{ }^{\circ} \mathrm{C}$ at soil depth 5, 10, 15 and $20 \mathrm{~cm}$ respectively. While the soil temperature for traditional greenhouse were 16.4, 15.88, 16.17 and $16.46{ }^{\circ} \mathrm{C}$ at soil depth 5, 10, 15 and $20 \mathrm{~cm}$ respectively.

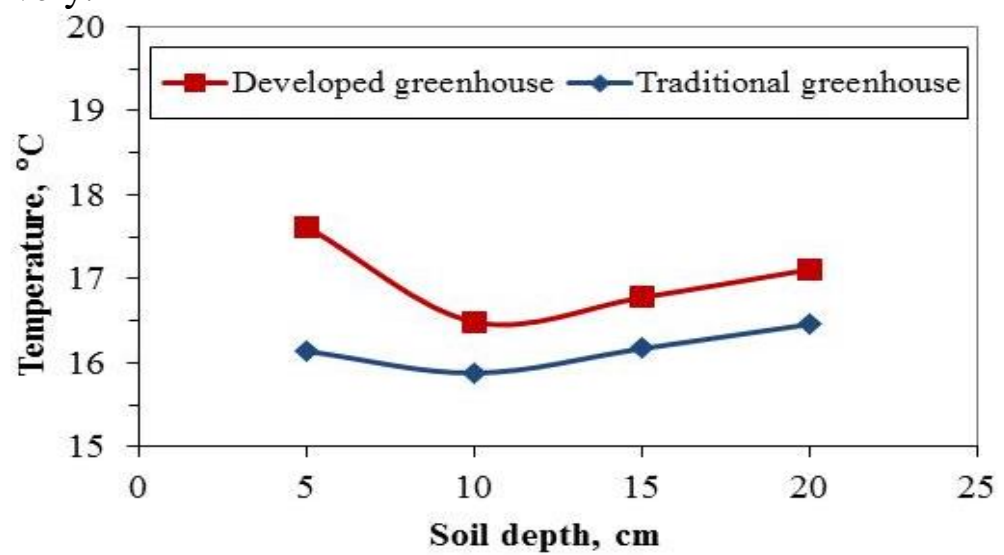

Fig. 6: Variation in soil average temperature with the changing in depth for both the developed and traditional greenhouses on $26^{\text {th }}$ November 2012.

The present study investigated that the highest soil temperature location was on the left- middle of the greenhouse for developed greenhouse and traditional greenhouse (Fig. 7). 

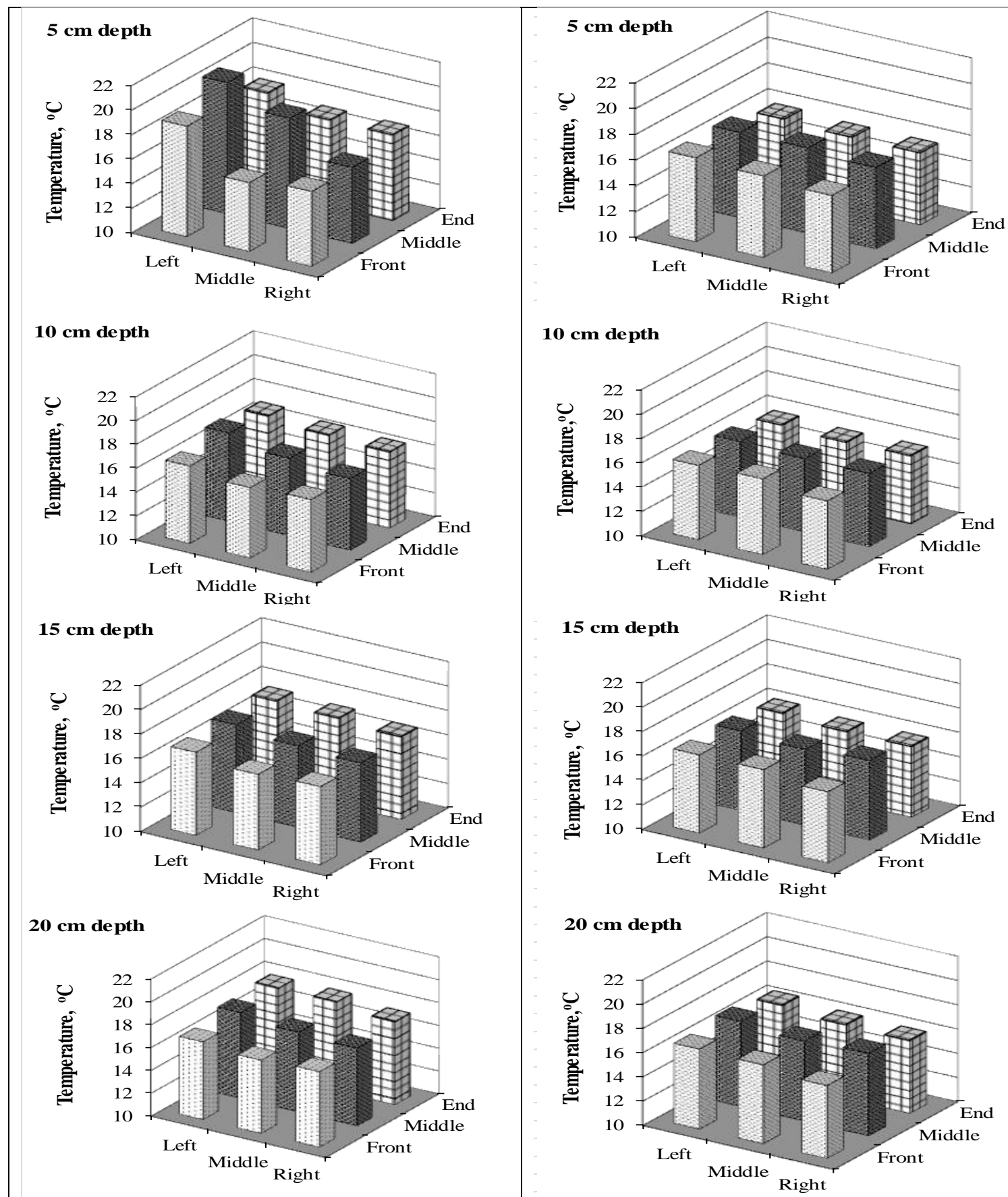

(A) Developed greenhouse

(B) Traditional greenhouse

Fig. 7: Soil Temperature distribution inside the greenhouses at four different depths $(5,10,15$ and 20cm): (A) Developed greenhouse at average temperature of $28{ }^{\circ} \mathrm{C}$ and (B) Traditional greenhouse at average temperature of $22^{\circ} \mathrm{C}$ on $26^{\text {th }}$ November 2012 . 
At soil depth $5 \mathrm{~cm}$, the highest values of soil temperature were $20.7^{\circ} \mathrm{C}$ and $16.6{ }^{\circ} \mathrm{C}$ for developed greenhouse and traditional greenhouse respectively. At soil depth $10 \mathrm{~cm}$, the highest values of soil temperature were $17.4{ }^{\circ} \mathrm{C}$ and $16.2{ }^{\circ} \mathrm{C}$ for developed greenhouse and traditional greenhouse respectively. At soil depth $15 \mathrm{~cm}$, the highest values of soil temperature were $17.2{ }^{\circ} \mathrm{C}$ and $16.5^{\circ} \mathrm{C}$ for developed greenhouse and traditional greenhouse respectively. At soil depth $20 \mathrm{~cm}$, the highest values of soil temperature were $17.5{ }^{\circ} \mathrm{C}$ and $17{ }^{\circ} \mathrm{C}$ for developed greenhouse and traditional greenhouse respectively.

\subsubsection{Air temperature inside greenhouse:}

Pepper cultivation in the greenhouse in November to provide the appropriate temperature for growth and particular attention must provide this heat when agriculture so as not to die of seedlings. Therefore, the following discussion on temperatures is focused on the period from $20^{\text {th }}$ November to $19^{\text {th }}$ December conditions as the critical period. The daily average temperature inside solar developed greenhouse varied from 20 ${ }^{\circ} \mathrm{C}$ to $25{ }^{\circ} \mathrm{C}$ while the daily average temperature inside traditional greenhouse varied from $16.3{ }^{\circ} \mathrm{C}$ to $24.3{ }^{\circ} \mathrm{C}$ when the outside temperature fluctuated between $13{ }^{\circ} \mathrm{C}$ and $20^{\circ} \mathrm{C}$ (Table 1). It was noticed that the lowest mean temperature inside the developed greenhouse and traditional greenhouse were $20{ }^{\circ} \mathrm{C}$ and $16.3{ }^{\circ} \mathrm{C}$ respectively occurred when the outside temperature $13{ }^{\circ} \mathrm{C}$ at $11^{\text {th }}$ December 2012. The highest average temperature inside the developed greenhouse and traditional greenhouse were $25{ }^{\circ} \mathrm{C}$ and $24.3{ }^{\circ} \mathrm{C}$ respectively occurred when the outside temperature $20{ }^{\circ} \mathrm{C}$ at $20^{\text {th }}$ November 2012. It was noticed that the temperature at the night was lower than the temperature at the day light for the developed greenhouse, traditional greenhouse and outside. The distribution of outside temperature was fairly symmetric, whereas the inside temperature distribution was good symmetric for developed greenhouse and traditional greenhouse (Table 1). On the other hand, the distribution of temperature inside developed greenhouse was the best of traditional greenhouse. 
The daily mean heat loss values determined through the period from $20^{\text {th }}$ November 2012 to $19^{\text {th }}$ December 2012 as shown in (Table 1). Through the nature of the climate in Egypt, we can say that heat loss occurs during night hours. As can be seen from the (Table 1), the highest daily mean heat losses values were 8.29 and $5.1 \mathrm{~kW}$ for developed greenhouse and traditional greenhouse respectively. The lowest values of daily mean of heat losses were 5.2 and $3.4 \mathrm{~kW}$ for developed greenhouse and traditional greenhouse respectively. It is clear also that the heat losses depend on the temperature difference between inside the greenhouse and outside the greenhouse.

\subsection{Heat index:}

The Heat Index uses temperature and the relative humidity to determine how hot the air actually "feels." When humidity is low, the apparent temperature will be lower than the air temperature, since perspiration evaporates rapidly to cool the body. However, when humidity is high (i.e., the air is more saturated with water vapor) the apparent temperature "feels" higher than the actual air temperature, because perspiration evaporates more slowly.

The Heat Index is a measure of the combined effects of temperature and atmospheric moisture on the ability of the plant (pepper) to dissipate heat. Periods of very high Heat Index have been associated with adverse human health consequences (Kalkstein and Smoyer 1993). The Heat Index (as used in this study, and which we refer to as the 'Steadman Heat Index') is a measure of the stress imposed on plant by elevated levels of atmospheric moisture. These conditions inhibit the ability of the plant to dissipate heat through evaporation, thereby causing discomfort. The heat index was varied from $13.15{ }^{\circ} \mathrm{C}$ and $38.45{ }^{\circ} \mathrm{C}$ for traditional greenhouse while, the heat index varied from $12.1{ }^{\circ} \mathrm{C}$ and $32.5{ }^{\circ} \mathrm{C}$ for developed greenhouse (Fig. 8). Generally, the heat index was increased through the daylight period and decreased through the day night. According to the heat index chart, the developed greenhouse was more comfortable for pepper plants which has had a positive impact on plant growth and yield of pepper. 
Table 1: Presents the daily mean heat losses and the average temperature for traditional greenhouse, developed greenhouse and outside through the period from $20^{\text {th }}$ November 2012 to $12^{\text {th }}$ December 2012.

\begin{tabular}{|c|c|c|c|c|c|}
\hline \multirow[b]{2}{*}{ Date } & \multicolumn{3}{|c|}{ Temperature, ${ }^{\circ} \mathrm{C}$} & \multicolumn{2}{|c|}{ Heat losses, kW } \\
\hline & Outside & $\begin{array}{l}\text { Developed } \\
\text { greenhouse }\end{array}$ & $\begin{array}{l}\text { Traditional } \\
\text { greenhouse }\end{array}$ & $\begin{array}{l}\text { Developed } \\
\text { greenhouse }\end{array}$ & $\begin{array}{l}\text { Traditional } \\
\text { greenhouse }\end{array}$ \\
\hline $20 / 11 / 2012$ & 20 & 25 & 24.3 & 5.2 & 4.4 \\
\hline $21 / 11 / 2012$ & 17 & 23 & 21.5 & 6.2 & 4.7 \\
\hline $22 / 11 / 2012$ & 18 & 24 & 22.4 & 6.2 & 4.6 \\
\hline $23 / 11 / 2012$ & 19 & 24 & 23.4 & 5.2 & 4.5 \\
\hline $24 / 11 / 2012$ & 18 & 24 & 22.9 & 6.2 & 5.1 \\
\hline $25 / 11 / 2012$ & 17 & 23.5 & 21.9 & 6.7 & 5.1 \\
\hline $26 / 11 / 2012$ & 18 & 23.5 & 22.3 & 5.7 & 4.4 \\
\hline $27 / 11 / 2012$ & 17 & 23 & 21.2 & 6.2 & 4.4 \\
\hline $28 / 11 / 2012$ & 18 & 24 & 22.7 & 6.2 & 4.9 \\
\hline $29 / 11 / 2012$ & 18 & 24 & 22.9 & 6.2 & 5.1 \\
\hline $30 / 11 / 2012$ & 18 & 23 & 22.4 & 5.2 & 4.6 \\
\hline $01 / 12 / 2012$ & 17 & 23 & 21.7 & 6.2 & 4.9 \\
\hline $02 / 12 / 2012$ & 17 & 23 & 21.7 & 6.2 & 4.9 \\
\hline $03 / 12 / 2012$ & 18 & 23.5 & 22 & 5.7 & 4.2 \\
\hline $04 / 12 / 2012$ & 15 & 22.5 & 19.8 & 7.8 & 5 \\
\hline $05 / 12 / 2012$ & 14 & 22 & 18.1 & 8.3 & 4.3 \\
\hline $06 / 12 / 2012$ & 16 & 23 & 20.3 & 7.3 & 4.4 \\
\hline $07 / 12 / 2012$ & 16 & 22.5 & 20.5 & 6.7 & 4.7 \\
\hline $08 / 12 / 2012$ & 17 & 23 & 21.3 & 6.2 & 4.4 \\
\hline $09 / 12 / 2012$ & 16 & 22.5 & 20.1 & 6.7 & 4.2 \\
\hline $10 / 12 / 2012$ & 15 & 22.5 & 18.4 & 7.8 & 3.6 \\
\hline $11 / 12 / 2012$ & 13 & 20 & 16.3 & 7.3 & 3.4 \\
\hline $12 / 12 / 2012$ & 15 & 21 & 18.9 & 6.2 & 4.1 \\
\hline $13 / 12 / 2012$ & 15 & 21.5 & 19.6 & 6.7 & 4.7 \\
\hline $14 / 12 / 2012$ & 14 & 22 & 18.4 & 8.3 & 4.6 \\
\hline $15 / 12 / 2012$ & 14 & 21.5 & 18.2 & 7.8 & 4.3 \\
\hline $16 / 12 / 2012$ & 14 & 21 & 18.8 & 7.3 & 5 \\
\hline $17 / 12 / 2012$ & 14 & 21.5 & 18.4 & 7.8 & 4.5 \\
\hline $18 / 12 / 2012$ & 15 & 22 & 19.4 & 7.3 & 4.6 \\
\hline $19 / 12 / 2012$ & 14 & 22 & 18.5 & 8.3 & 4.7 \\
\hline
\end{tabular}




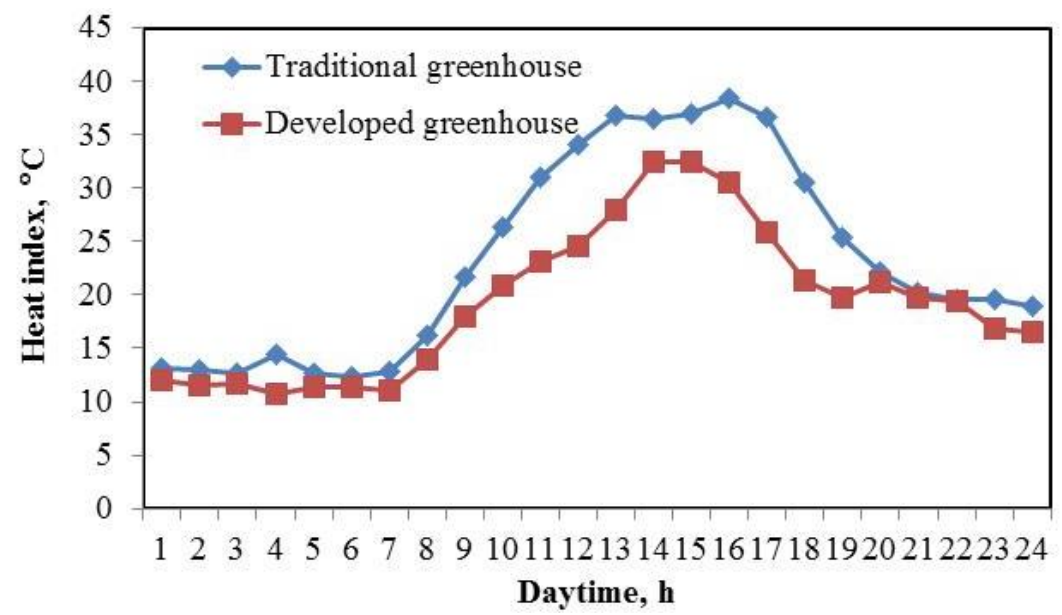

Fig. 8: Shows the heat index for developed greenhouse and traditional greenhouse through the whole day 11 March 2013.

\subsection{UV dose:}

(Fig. 9) presented the values of UV dose inside traditional greenhouse and developed greenhouse through the whole day. The UV dose values inside the developed greenhouse were higher than the UV dose inside the traditional greenhouse. The highest values of UV dose were 13 and 10.2 $\mathrm{mJ} . \mathrm{cm}^{-2}$ for developed greenhouse and traditional greenhouse respectively. The UV dose meter was recorded reading from 7 am O'clock to 4 pm O'clock. The highest values occurred at 2 pm O'clock.

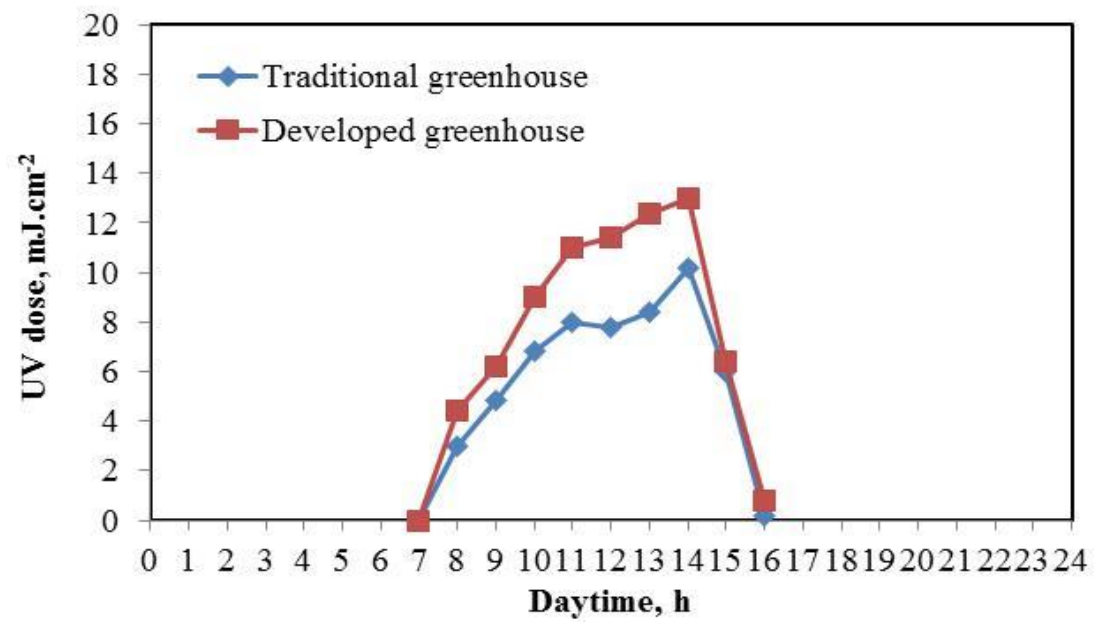

Fig. 9: shows the UV dose for developed greenhouse and traditional greenhouse through the whole day 11 March 2013. 


\subsection{Heating and cooling degree days:}

One of significant meteorological variables that relate to greenhouse energy consumption is heating (HDD) and cooling degree-days (CDD). Both of them are basic quantities for preliminarily estimating energy consumption of a building. The number of degree hours accumulated in a day is a measure of the energy load to maintain a greenhouse at a base temperature. In empirical practice, there is a significant correlation between HDD and thermal energy load. HDD and CDD represent the number of degrees over a period in which the temperature is lower (or higher) than a base level. HDD are intended to proxy the thermal load requirements to maintain the interior temperature at a base temperatures. HDD and CDD can be calculation according to (Clyde, 2011) as follows:

$\mathrm{HDD}$ or $\mathrm{CDD}=\mathrm{T}_{\mathrm{opt}}-\left(\left(\mathrm{T}_{\max }+\mathrm{T}_{\min }\right) / 2\right)$ Where:

$\mathrm{T}_{\text {opt }}$ is the required temperature, ${ }^{\circ} \mathrm{C}$.

$\mathrm{T}_{\max }$ is the maximum temperature, ${ }^{\circ} \mathrm{C}$.

$\mathrm{T}_{\min }$ is the minimum temperature, ${ }^{\circ} \mathrm{C}$.

(Fig. 10) shows the HDD and CDD for developed greenhouse and traditional greenhouse through the whole day. Part of the curve above the axis represents CDD (occur during daylight hours and after sunset several hours) while the part of the curve lower axis represents HDD (occurs during the late hours of the night).

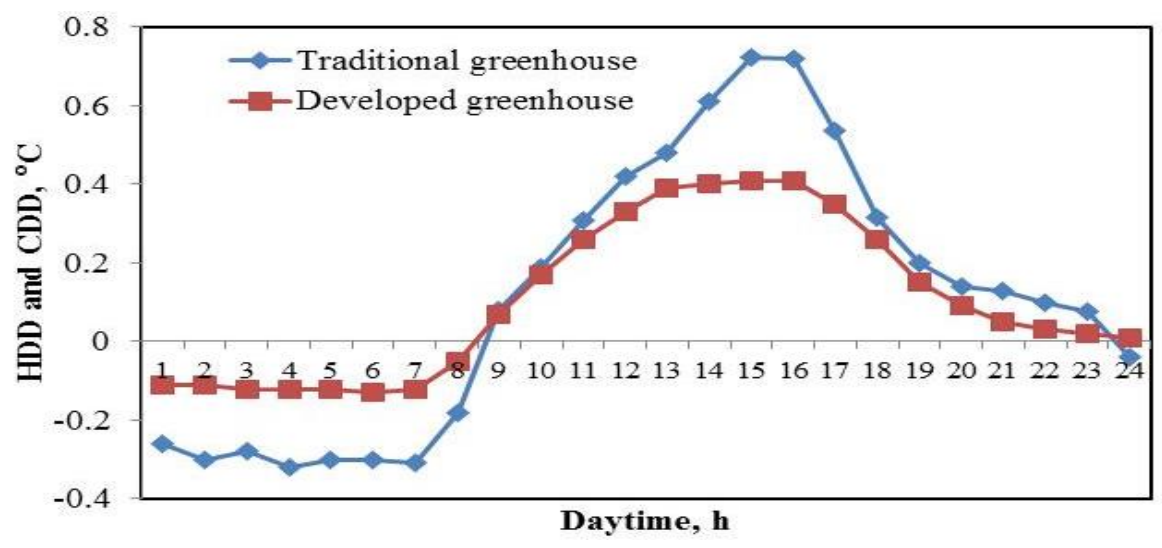

Fig. 10: presents the heating (HDD) and cooling degree days (CDD) for developed greenhouse and traditional greenhouse through the whole day 11 March 2013. 
The highest values of CDD were $0.7{ }^{\circ} \mathrm{C}$ and $0.4{ }^{\circ} \mathrm{C}$ for traditional greenhouse and developed greenhouse respectively. The highest values of HDD were $0.3{ }^{\circ} \mathrm{C}$ and $0.1{ }^{\circ} \mathrm{C}$ for traditional greenhouse and developed greenhouse respectively. Generally, the developed greenhouse was lowering needy to CDD and HDD than traditional greenhouse. This means that the temperature inside the developed greenhouse was closer to the optimum temperature than traditional greenhouse.

\subsection{Agronomic performance:}

The heating system for developed greenhouse has a significant agronomic effect especially on the precocity of the production. (Table 2) shows the Vegetative growth of pepper plant grown in developed greenhouse and traditional greenhouse after days of transplanting.

Developed greenhouse was better than traditional greenhouse for all parameters. (Table 3) presents the early yield and yield components of pepper plant grown in developed greenhouse and traditional greenhouse. Specification of developed greenhouse yield was better than traditional greenhouse especially second packing for all parameters.

Table 2: Vegetative growth of pepper plant grown in developed greenhouse and traditional greenhouse after days of transplanting.

\begin{tabular}{|l|c|c||c|c|}
\hline \multirow{2}{*}{ Parameter } & \multicolumn{2}{|c||}{ Developed greenhouse } & \multicolumn{2}{c|}{ Traditional greenhouse } \\
\cline { 2 - 5 } & $25 / 11 / 2012$ & $25 / 12 / 2012$ & $25 / 11 / 2012$ & $25 / 12 / 2012$. \\
\hline Plant height (cm) & 50.7 & 78 & 40 & 69.3 \\
No. of leaves/ plant & 47.7 & 142 & 38 & 99 \\
No. of branches/ plant & 23 & 72 & 13.33 & 40 \\
Top fresh weight/ plant (g) & 66 & 245.7 & 32.33 & 224 \\
Leaves fresh weight/ plant (g) & 32.7 & 93.3 & 18 & 49.3 \\
Stems fresh weight/ plant (g) & 22.3 & 89.7 & 13.33 & 45.3 \\
Top dry weight/ plant (g) & 8.28 & 29.38 & 4.64 & 17.66 \\
Leaves dry weight/ plant (g) & 4.80 & 15.95 & 2.85 & 9.66 \\
Stems dry weight/ plant (g) & 3.48 & 13.43 & 1.79 & 8.00 \\
Plant leaf area (dm ${ }^{2}$ ) & 17.33 & 33.17 & 13.14 & 21.87 \\
Chlorophyll (SPAD) & 52.3 & 59.9 & 55.4 & 67.6 \\
Fruits number/ plant & - & 9.5 & - & 6.3 \\
Fruits weights/ plant (g) & - & 60 & - & 26.7 \\
\hline
\end{tabular}


Table 3: Early yield and yield components of pepper plant grown in developed greenhouse and traditional greenhouse.

\begin{tabular}{|l|c|c||c|c|}
\hline \multirow{2}{*}{ Parameter } & \multicolumn{2}{|c||}{$\begin{array}{c}\text { Developed } \\
\text { greenhouse }\end{array}$} & \multicolumn{2}{c|}{$\begin{array}{c}\text { Traditional } \\
\text { greenhouse }\end{array}$} \\
\cline { 2 - 5 } & $\begin{array}{c}\text { First } \\
\text { picking }\end{array}$ & $\begin{array}{c}\text { second } \\
\text { picking }\end{array}$ & $\begin{array}{c}\text { First } \\
\text { picking }\end{array}$ & $\begin{array}{c}\text { second } \\
\text { picking }\end{array}$ \\
\hline Total fruits yield/ plant (g) & 278.6 & 149.8 & 233.4 & 42.4 \\
No. of fruits/ plant & 3.4 & 2.6 & 3.8 & 1.0 \\
Total fruits yield/ greenhouse (kg) & 98.3 & 49.7 & 84.1 & 14.2 \\
No. of fruits/ greenhouse & 1203 & 876 & 1393 & 334 \\
First grade yield\% & 70.2 & 58.8 & 51.0 & 43.5 \\
Average fruit weight (g) & 81.72 & 56.76 & 60.4 & 42.16 \\
Average fruit length, L (cm) & 16.3 & 13.5 & 15.0 & 13.4 \\
Average fruit diameter, D (cm) & 5.0 & 4.7 & 4.2 & 4.7 \\
Fruit shape index (L/D) & 3.26 & 2.87 & 3.57 & 2.85 \\
\hline
\end{tabular}

\section{CONCLUSION}

The following conclusion can be drawn from this study:

- An increase of the temperature inside the developed greenhouse of about $2.1{ }^{\circ} \mathrm{C}$.

- The air temperature inside the developed greenhouse become a homogeneous.

- The soil temperature inside the developed greenhouse increased of about $0.8^{\circ} \mathrm{C}$ at $5 \mathrm{~cm}$ depth.

- Pepper crop specification of developed greenhouse yield was better than traditional greenhouse

In addition, by homogenizing the microclimate inside the greenhouse, the system allowed to reduce the dispersion and the multiplicity of grades, and obtain a very good agronomic efficiency. For the same planting density in both greenhouses, the total fruits yield per plant $(\mathrm{g})$ for first picking were 278.6 and $233.4 \mathrm{~g}$ for developed greenhouse and traditional greenhouse respectively. 


\section{Acknowledgements:}

This material is based upon work supported by Kafrelsheikh University, Faculty of Agriculture under project number KFURF07 and funded by the fund to support research university. The author would like to sincerely thank Prof. Dr. Farouk El Aidy Emeritus Professor of Vegetables, Horticulture Department, Faculty of Agriculture, Kafrelsheikh University, Egypt for his efforts and facilitating some materials during experimentation.

\section{REFERENCES}

Badescu, V. (2002). First and second law analysis of a solar assisted heat pump based heating system, Energy Conversion and Management 43: 2539-2552.

Bargach M.N., A.S. Dahman and M. Boukallouch (1999). A heating system using flat plate collectors to improve the inside greenhouse microclimate in Morocco. Renewable Energy 18 : 367-381.

Bargach M.N., R. Tadili, A.S. Dahman and M. Boukallouch (2004). Comparison of the performance of two solar heating systems used to improve the microclimate of agricultural greenhouses in Morocco. Renewable Energy 29 : 1073-1083.

Bargach M.N.; A.S. Dahman and M. Boukallouchc (1999). A heating system using flat plate collectors to improve the inside greenhouse microclimate in Morocco. Renewable Energy , 18: 367-381.

Bascetincelik, A. ; H.H. Ozturk; H.O. Paksoy and Y. Demirel (1999). Energetic and exergetic efficiency of latent heat storage system for greenhouse heating, Renewable Energy 16: 691-694.

Chinese D.; A.Meneghetti and G.Nardin (2005). Waste-to-energy based greenhouse heating: exploring viability conditions through optimisation models. Renew Energy;30(10):1573-86.

Clyde W. F.; J. Bellow and C. Brown (2011). Degree Days: Heating, Cooling, and Growing: one of a series of the Agricultural and Biological Engineering Department, Florida Cooperative Extension 
Service, Institute of Food and Agricultural Sciences, University of Florida. Visit the EDIS website at http://edis.ifas.ufl.edu.

De Halleux D. (1989).Modele dynamique des echanges energetiques des serres; etude theorique et experimentale. These de Doctorat es Sciences Agronomiques, Faculte des Sciences Agronomiques de Gembloux, Belgique.

De Halleux D.; J. Nisjkens and J.Deltour (1991). Adjustement and validation of a greenhouse climate dynamic model. Bull Rech Agron Gembloux 26(4): 42-5.

Esen M. and T. Yuksel (2013). Experimental evaluation of using various renewable energy sources for heating a greenhouse. Energy and Buildings $65: 340-351$.

Gamea, G. R.; M. A. Abd El-Maksoud and M. N. Omar (2011). Mathematical model for greenhouse heating by waste heat from biogas fuel engine. Misr J. Ag. Eng., 28(3): 734-758.

Ghosal, M.K. ; G.N. Tiwari and N.S.L. Srivastava (2004). Thermal modeling of a greenhouse with an integrated earth to air heat exchanger: an experimental validation, Energy and Buildings 36: 219-227.

Kalkstein, L. S. and K. E.Smoyer (1993). The Impact of Climate Change on Human Health: Some International Implications', Experientia 49, 969-979.

Mezrhab A., L. Elfarh, H. Naji and D. Lemonnier (2010). Computation of surface radiation and natural convection in a heated horticultural greenhouse. Applied Energy 87: 894-900.

Ozgener O.; L. Ozgener and D.Y. Goswami (2011). Experimental prediction of total thermal resistance of a closed loop EAHE for greenhouse cooling system, International Communications in Heat and Mass Transfer $38: 711-716$. 
Ozgener, O. and G. Kocer (2004). Geothermal heating applications, Energy Sources 26 (4) : 353-360.

Seginer, I. and D. L.Albright (1980). Rational operation of greenhouse thermal-curtains. Transaction of the ASAE 1980:1240-45.

Tantau, H. J. (1998). Greenhouse climate - overview. Modelling, control and optimization greenhouse, draying and farm energy system.

Teitel M., M.; Barak and A. Antler (2009). Effect of cyclic heating and a thermal screen on the nocturnal heat loss and microclimate of a greenhouse. biosystems engineering $102: 162-170$.

Wang S.; J.Deltour; J.Nijskens and Ph.Wergifosse (1990). Exact enalytical solution of a linear dynamic model of greenhouse climate: the direct cover case. Bull Rech Agron Gembloux, 25(4): 489-518.

Wikimedia Foundation (2010). Inc. Heat Index.

http://en.wikipedia.org/wiki/Heat_index.

Zabeltitz C.(1992). Energy efficient greenhouse designs for Mediterranean countries. Plasticulture 96 (4): 6-16.

Zhang Z., G.Pirard; E.Massaux and J.Deltour (993). A Gembloux greenhouse dynamique model. Service de Physique, Faculte des Sciences Agronomiques de I'Etat, Gembloux, Belgique.

\section{الملخص العربي}

تظوير صوبة زراعية باستخدام الطاقة الشمسية لانتاج محصول الفلقل السباعي ع. م.

تهدف هذه الدراسة الي استخدام الطاقة الثمسية كأحد مصادر الطاقة المتجددة في تحسين

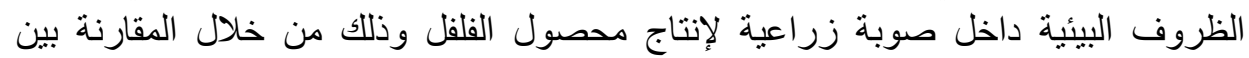

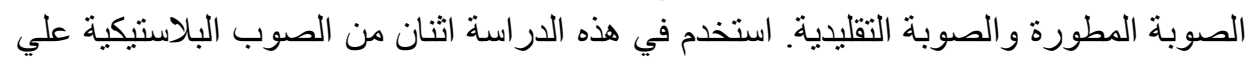

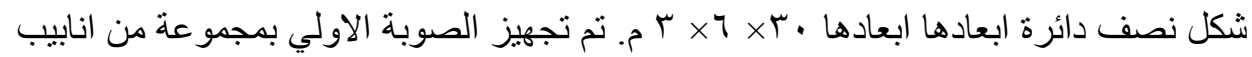

* مدرس الهندة الزراعية ـ قسم الهندسة الزراعية ـ كلية الزراعة ـ جامعة كفر الثيخ 
بقطر 0 سم وتم توصيلها بمجمع شمسي ذو انابيب مفرغة لتدفئة الصوبة (الصوبة المطورة) اما الصوبة الثانية فكانت بدون اي مصدر للتدفئة (صوبة تقليدية). واوضحت نوت نتائج

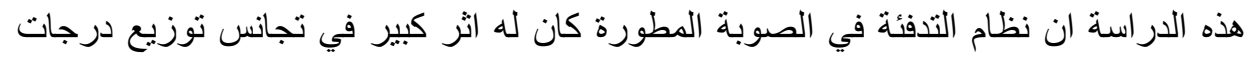

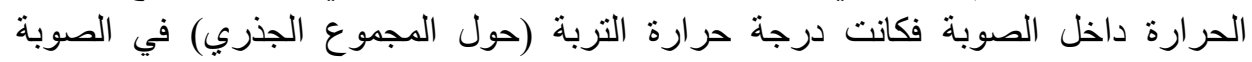

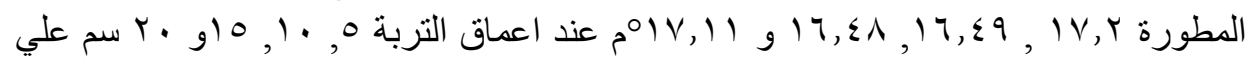

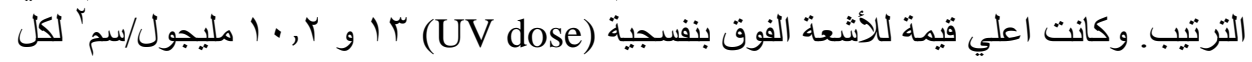
من الصوبة المطورة والصوبة التقليدية علي الترتيب. وكانت اعلي قيمة الاحتياج الحراري

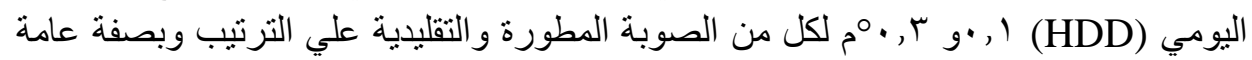
كانت الصوبة المطورة اقل في HDD و CDD من الصوبة التقليدية. نظام التدفئة في الصوبة

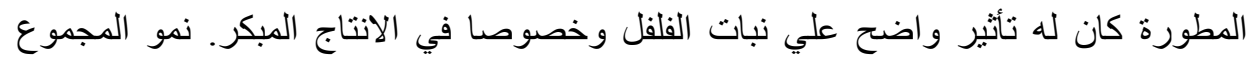

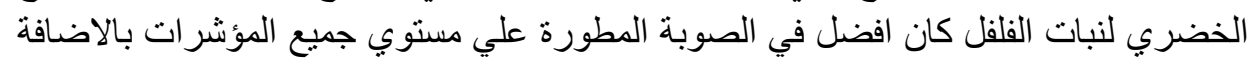
الي ان صفات محصول الفلفل الناتج من الصوبة المطورة افضل من الصوبة التقليدية 